\title{
IMMUNOMODULATORY EFFECTS OF THYME AND FENUGREEK IN SHARPTOOTH CATFISH, CLARIAS GARIEPINUS
}

\author{
WALAA F.A. EMEISH ${ }^{1}$ and AYA G. SAAD EL-DEEN ${ }^{2}$ \\ ${ }^{1}$ Fish Diseases and Management, Department of Fish Diseases and Management, Faculty of Veterinary Medicine, South \\ Valley University, Qena \\ ${ }^{2}$ Fish Diseases and Management, Animal Health Research Institute, Assiut Laboratory
}

Received: 24 May 2016; $\quad$ Accepted: 28 June 2016

\begin{abstract}
The aim of this study was to investigate the modulation effects of thyme and fenugreek as food additives on sharptooth catfish immunity. Three diet regimes, a basic (control); Thyme diet (1\%) and fenugreek diet (1\%) were formulated and used to feed fish for 30 successive days. Half of the fish were used to investigate some of the immune parameters as differential leucocytic counts, serum globulins, phagocytic activities, phagocytic index, catalase and glutathione peroxidase. The other half of fish was subjected to challenge infection with Aeromonas hydrophila to investigate the disease resistance ability of the fish received the feeding additives. The results showed that, the serum globulins have significantly increased in fish fed with fenugreek, while the total serum protein has significantly increased in fish fed with thyme or fenugreek. Glutathione peroxidase (Gper) and catalase (CAT) increased significantly in the groups fed on fenugreek or thyme diets when compared to the control group. Phagocytic percent and index of fish fed on fenugreek were significantly higher than those of the control and thyme groups. Monocytes were significantly increased in all treated groups, while lymphocytes were significantly decreased in all treated groups. Weight gain of $C$. gariepinus was significantly lower in the group fed on thyme than in the control group, while it was insignificantly higher in fish fed fenugreek. After 30 days of feeding, fish were challenged with A. hydrophila, the cumulative mortalities were $40 \%$ and $26.67 \%$ in fish fed on diet supplemented with $1 \%$ thyme and fenugreek, respectively, compared to $66.7 \%$ in the control group. It was concluded that thyme and fenugreek are be able to positively stimulate the immune system of $C$. gariepinus and decrease mortality rate in fish challenged with A. hydrophila.
\end{abstract}

Key words: Catfish, Thyme, Fenugreek, Immunostimulant effect.

\section{INTRODUCTION}

Fish are exposed to pathogenic microorganisms since they live in an unfavorable environment (Yunxia et al., 2001). Antibiotics and chemotherapeutics have been used to prevent or control bacterial infections in aquaculture for about 20 years (Sakai, 1999). Unfortunately, antibiotics treatment is not successful and sustainable due to increase antibiotic-resistant in bacteria, negative effects on the indigenous microflora of juveniles or adult fish (Balfry and Higgs, 2001), accumulation of antibiotic residues in fish tissue and environment causing human and animal health issues. Vaccination is an effective prophylactic treatment for infectious diseases in fish culture, but it may be very expensive and stressful to fish. A single vaccine is effective against only one specific type of pathogen, but limits the effectiveness for wide range of pathogens due to

Corresponding author: AYA G. SAAD EL-DEEN

E-mail address: aya9galal@gmail.com

Present address: Fish Diseases and Management, Animal Health Research Institute, Assiut Laboratory the complex antigenic structure (Ardo et al., 2008). Therefore using natural food additives has been important to minimize these adverse effects (Abd ElLatif et al., 2004).

In fish culture, there are various active components such as Allium sativum (garlic), Zingiber officinale (ginger), Curcuma longa Linn (turmeric), Trigonella foenum-graecum (fenugreek) and others which have been reported to promote various effects like higher growth rates (Shalaby et al., 2006), appetite stimulation, antistress, immune functions (Dügenci et al., 2003; Dorucu et al., 2009; Ergün et al., 2011), skin coloration (Y1lmaz and Ergün, 2011), egg hatching rates (Y1lmaz and Ergün, 2012a), hematological and biochemical status (Y1lmaz and Ergün, 2012b) and also increase disease resistance (Y1lmaz et al., 2012; Y1lmaz et al., 2013). Several studies have showed that oral administration of fenugreek in Labeo rohita and Oreochromis mossambicus (Paul et al., 2004; Mostafa et al., 2009), rosemary in O. niloticus (Abutbul et al., 2004; Zilberg et al., 2010), thyme, rosemary and fenugreek in O. mossambicus (Ergün et al., 2011) improved 
growth performance, disease resistance and increase immunity.

The aim of the present study was to investigate the effects of thyme and fenugreek supplementation diet on some immunological parameters and disease resistance of sharptooth catfish $C$. gariepinus to Aeromonas hydrophila.

\section{MATERIALS AND METHODS}

Fish

200 live African sharptooth catfish, Clarias gariepinus were obtained from a private fish farm at El-Dakahlea Government and transported under hygienic control to the wet laboratory, Faculty of Veterinary Medicine, South Valley University, Qena. Fish were acclimated for 21 days in porcelain aquaria $(260 \times 65 \times 70 \mathrm{Cm})$ according to the protocol of maintaining bioassay fish as was previously described (Ellsaesser and Clem, 1986).

\section{Diets and feed additives}

Three different diets with or without feed additives in the form of dry pellets, representing 3 diet variants, were formulated to be used in feeding of fish. The experimental diet was prepared using a hand palletizer. The basic diet, (control) was formulated of grounded yellow corn $34.9 \%$, vegetable bean meal $28.6 \%$, fish meal $17.0 \%$, wheat bran $9.3 \%$, mineral mixture $1.7 \%$ and vitamin mixture $1.0 \%$. The two other experimental diets were formulated as a Fenugreek diet (basic diet with $1 \%$ of Trigonella foenum-graecum fenugreek) and thyme diet (basic diet with $1 \%$ Thymus vulgaris, thyme). Fenugreek and thyme were obtained from the local market in the form of powder.

\section{Experimental design}

One hundred and twenty acclimated apparently healthy African sharptooth catfish, $C$. gariepinus were randomly selected with a body weight range of $40-90 \mathrm{~g}$ to be used for the experiment groups. The experiment was done in 3 replicates (40 fish each) where fish in each replicate were divided into 2 sets, one set was used for evaluating the immune blood parameters of fish (blood set) while the other set was used for challenge experiment (challenge set). The blood set has three equal groups that represent the three nutritional treatments (corresponding to the three diets variants) with 15 fish in each. Control group received the basic diet, the second group received the thyme diet and the third group received the fenugreek diet. The challenge set has the same three groups as the first set, but with 2 additional nonchallenge control groups. These two groups received the basic diet, where one group of which was injected with distilled water, while the other one remained uninjected. Each group was fed twice daily for 30 successive days. At the end of the 30 days feeding; blood samples were taken from the caudal vein from each group to measure the immune and hematological parameters.

\section{Hematological studies}

By the end of the feeding experiment, fish of all groups of the blood sets were anasthetized using tricaine methanesulfonate (MS-222, Argent Chemical Labs, Redmond, Washington, USA), and blood samples were collected from the caudal vein and the samples were divided into 2 portions. Sodium citrate (3\%) was added to one part for differential leukocytic count and phagocytic assay. The second part of blood sample was allowed to clot, centrifuged for serum separation. Total proteins and albumin were determined by "Protein" and "Albumin" kits (Spectrum, Egyptian Company for Biotechnology, Obour City, Cairo, Egypt) according to manufacture's recommedation. Globulin levels were calculated mathematically by subtracting albumin value from total protein value and expressed in $\mathrm{g} / \mathrm{dl}$ according to Khalil, (2000). Catalase assay was calculated according to Aebi (1984) using catalase kits (Biodiagnostic test kits). Glutathione peroxidase were measured according to Paglia and Valentine (1967) using Biodiagnostic test kits.

\section{Phagocytosis assay}

Phagocytic assay was done according to Kwahara et al. (1991). Fifty $\mu \mathrm{g}$ Candida albicans culture was added to $1 \mathrm{ml}$ of citrated blood collected from fish and shaken in water bath at $25^{\circ} \mathrm{C}$ for 5 hours. Smears of the blood were then stained with Giemsa stain. Phagocytosis was estimated by determining the proportion of phagocytic cells which contained intracellular yeast cells in a random count of 200 phagocytes (Abu-Elala et al., 2013) and expressed as percentage of phagocytic activity (PA). The number of phagocytized yeast cells was counted in the phagocytic cells to estimate the phagocytic index (PI).

\section{Experimental challenge test}

Bacterial strain: An Aeromonas hydrophila strain isolated from clinical cases of infected C. gariepinus showing signs of septicemia, were used in the experimental infection. The strain was identified by Gram stain, motility test, and various biochemical characters according to Austin and Austin (2007) and preserved in glycerol at $-80^{\circ} \mathrm{C}$. The Aeromonas hydrophila strain was passed three times in healthy sharptooth catfish through intraperitoneal injection before using for experimental challenge.

\section{Bacterial challenge suspension and counts}

Colony forming units (cfu) counts in bacterial suspensions were determined using spectrophometery optical density values at wavelength of $600 \mathrm{~nm}$ and standard-plate-count method with ten-fold serial dilution (Elkamel and Thune, 2003). 


\section{Experimental challenge}

The challenge groups of each challenge set were challenged through $\mathrm{I} / \mathrm{P}$ injection with $0.5 \mathrm{ml}$ of sterile saline containing $0.3 \times 10^{6} \mathrm{cfu} / \mathrm{ml}$ pathogenic strain of Aeromonas hydrophila. One group of the challenged set was injected with sterile saline (sham control) and another group was left un- injected as a control. The clinical signs, post mortem lesions and mortalities were recorded daily for up to two weeks. Re-isolation and identification of bacteria was done from freshly dead fish as mentioned above.

\section{Statistical analysis:}

Statistical analysis was carried out using of S.A.S. (2001) program, version 8.2. The significance differences between treatments means were tested by Duncan Multiple Range test (Steel and Torrie, 1982). Data was presented in means \pm standard error of means (S.E.M). Level of significance was set at $<0.05$.

\section{RESULTS}

Serum total protein and globulin values were significantly higher in fish supplement with thyme and fenugreek when compared to the control group. Higher value of globulins was observed in fish supplemented with fenugreek. Phagocytic percent and phagocytic index of catfish received fenugreek diet were significantly higher than those of the other groups. Serum of fish fed on diet with thyme and fenugreek showed significant increase in the glutathione peroxidase and catalase activities compared to fish fed on basic diet. There was insignificant increase in total weight gain in fish fed on fenugreek diet compared to the thyme and control groups, but there were significant decrease in total weight gain in fish fed on thyme diet compared to other groups. Cumulative mortalities of catfish challenged with $A$. hydrophila were significantly less in fish fed on fenugreek diets than that of fish fed on thyme or basic diets (table 1).

Table 1: Effect of thyme and fenugreek diets on some haematological and immunological parameters of sharptooth catfish.

\begin{tabular}{|c|c|c|c|}
\hline Parameter & $\begin{array}{c}\text { Basic(control) } \\
\mathrm{n}=15\end{array}$ & $\begin{array}{c}\text { Thyme diet } \\
n=15\end{array}$ & $\begin{array}{l}\text { Fenugreek diet } \\
n=15\end{array}$ \\
\hline Lymphocyte $\%$ & $40.75 \pm 3.84^{\mathrm{a}}$ & $36.25 \pm 1.015^{b}$ & $35.417 \pm 0.949^{b}$ \\
\hline Monocyte $\%$ & $34.833 \pm 3.214^{\mathrm{a}}$ & $37.75 \pm 1.045^{b}$ & $38.333 \pm 1.548^{b}$ \\
\hline Neutrophil $\%$ & $13.917 \pm 2.778^{\mathrm{a}}$ & $14.166 \pm 0.833^{\mathrm{a}}$ & $14.666 \pm 0.837^{\mathrm{a}}$ \\
\hline Basophile \% & $8.666 \pm 1.669^{\mathrm{a}}$ & $8.833 \pm 0.660^{\mathrm{a}}$ & $8.583 \pm 0.701^{\mathrm{a}}$ \\
\hline Eosinophil \% & $1.833 \pm 0.717^{\mathrm{a}}$ & $3 \pm 0.246^{b}$ & $3 \pm 0.213^{b}$ \\
\hline Phagocytic \% & $26.416 \pm 3.528^{\mathrm{a}}$ & $27.978 \pm 1.019^{\mathrm{ab}}$ & $29.291 \pm 0.568^{b}$ \\
\hline Phagocytic index & $1.075 \pm 0.033^{\mathrm{a}}$ & $1.122 \pm 0.027^{\mathrm{ab}}$ & $1.190 \pm 0.042^{b}$ \\
\hline Total protein $\mathrm{mg} / \mathrm{dl}$ & $3.17 \pm 0.202^{\mathrm{a}}$ & $3.80 \pm 0.196^{b}$ & $4.29 \pm 0.157^{\mathrm{c}}$ \\
\hline Albumin & $1.17 \pm 0.07^{\mathrm{a}}$ & $1.48 \pm 0.13^{b}$ & $1.71 \pm 0.08^{\mathrm{b}}$ \\
\hline Globulin & $2 \pm 0.174^{\mathrm{a}}$ & $2.32 \pm 0.130^{\mathrm{ab}}$ & $2.58 \pm 0.172^{b}$ \\
\hline Glutathione peroxidase $\mathrm{mU} / 1$ & $0.31 \pm 0.037^{\mathrm{a}}$ & $0.48 \pm 0.051^{b}$ & $0.52 \pm 0.060^{b}$ \\
\hline Catalase U/ 1 & $319.28 \pm 11.413^{a}$ & $360.78 \pm 15.130^{b}$ & $377.62 \pm 13.144^{b}$ \\
\hline total weight gain gm & $2.833 \pm 0.548^{a}$ & $1.583 \pm 0.259^{b}$ & $3.166 \pm 0.423^{\mathrm{a}}$ \\
\hline Cumulative Mortality percent & $66.7 \%$ & $40 \%$ & $26.67 \%$ \\
\hline
\end{tabular}

Means in the same raw with different letters are significantly different $(\mathrm{p}<0.05)$.

\section{DISCUSSION}

Strengthening the defense mechanism of fish through prophylactic administration of natural plant products is one of the most promising methods of controlling diseases in aquaculture (Agarwal and Singh 1999; Devasagayam and Sainis 2002) and is considered a promising alternative to chemotherapy and vaccines (Secombes, 1994). Using natural plants as immunostimulants in fish is more useful than using of antibacterial drugs that cause adverses side effects for fish, environment and consumers. Therefore, we investigated the effects of thyme (Thymus vulgaris) and fenugreek (Trigonella foenum-graecum), as herbal medicine plants on some immunological, hematological parameters and defense mechanisms of sharptooth catfish, Claries gariepinus after 30 days of feeding.

Results indicated that fenugreek improved body weight gain of $C$. gariepinus. These results could be attributed to the action of fenugreek as appetizer (Coutteau et al., 2011). In addition (Frankic et al., 2009) reported herbs stimulate the secretion of pancreatic enzymes, important factors in nutrient digestion and assimilation. This can explain the higher, though not significant, weight gain obtained 
with fenugreek supplementation. Several studies have reported that oral administration of fenugreek in Labeo rohita and Oreochromis mossambicus (Paul et al., 2004; Mostafa et al., 2009 and Ergün et al., 2011) improved growth performance, disease resistance and increased immunity.

The decrease in fish weight gain observed with thyme supplemented diets could be attributed to the antimicrobial activity of thyme which may be masked by diet composition and/or environment, in that no effect of thyme on growth performance (Lee et al., $2003 \mathrm{~b}$ ). These results are supported by those of Saleh et al. (2014) who showed that addition of thyme at the selected levels had no beneficial value on live body weights or body weight gain of broiler chicken at any time along the experimental period.

Several types of leukocytes participate in the cellular immune response, including lymphocytes, monocytes, granulocytes (neutrophils, eosinophils and basophils), and cytotoxic cells (Nakanishi, 1999). Fernández et al. (2002) recorded that macrophages can be used as indicators to evaluate the health of fish. These cells play an important role in killing pathogens as in immune response. In this study, monocyte have significantly increase in catfish fed diet contains $1 \%$ thyme or fenugreek when compared to basic diet which is in line with the results of Gültepe et al. (2014) who showed that monocyte was elevated in Oreochromis mossambicus fed with diets supplemented with thyme, rosemary and fenugreek.

Either increase or decrease in different leucocytes was pronounced in fish because all leucocytes were calculated as a percentage of the whole leucocytic count which constitutes $100 \%$. The decrease of the percentage of lymphocytes in fish groups may be attributed to the significant increase of other leucocytic cells.

The present study indicated that both phagocytic \% and phagocytic index of macrophages significantly increased in sharptooth catfish fed on fenugreek at concentration $1 \%$ in comparison with fish fed on thyme or basic diets. The enhancement of phagocyte function is one of the most immediate and key effects produced plant extracts on the host immune system of fish. This result supported by Gültepe et al. (2014) who reported, Oreochromis mossambicus fed with a diet supplemented with fenugreek significantly increased phagocytic activity compared to control group. Fenugreek is rich in flavonoids (such as apigenin, kaempferol and quercetin) and saponins (such as diosgenin and yamogenin) that protect cells from oxidative damage (Kaviarasan et al., 2004) and have immunostimulatory properties (Bin-Hafeez et al., 2003). On the other hand, thyme has no significant effect on phagocytosis. These results are in line with Pérez-Rosés et al. (2015) who investigated the in vitro activity of thyme on phagocytosis by human neutrophils. They showed inhibition in phagocytosis.

Blood serum protein is a fairly labile biochemical system, precisely reflecting the condition of the organism and the changes happening to it under influence of internal and external factors. The serum protein level is an important indicator of humoral defense system of fish and increases especially in the fish fed with plant extracts (Misra et al., 2006). In the current study total protein in serum was significantly higher in fish fed on diet containing fenugreek or thyme when compared to basic diet. An investigation done by Toghyani et al. (2011) proved that serum total protein and globulin concentrations increased significantly in birds fed diet supplemented with thyme powder. They attributed this increase to the components of thyme oils, thymol and carvacrols which possess potent antioxidant properties and consequently, elevate immune responses of chicks. Over and above, Tollba et al. (2010) found that mixture of volatile oils including thyme, oregano, C.verum and capsicum added to two groups of chicks diets at 1 or $2 \mathrm{~g} / \mathrm{kg}$ feed in the experimental period which lasted at 12 wks of age, increased the total protein significantly as well as albumin and globulin comparing to un-supplemented control group. Elevated serum total protien level may be due to high level of protein and other nutrients in T. foenumgraecum $L$ seeds. This could be supported by the idea of Hoffman (1966) who cited that, serum protein levels are sensitive to nutritional influences.

Globulins concentration is significantly higher in fish fed on $T$. foenum-graecum, supplement compared to the other groups. The increase in globulin levels may be due to the immune stimulant effect of $T$. foenumgraecum supplementation in his work, that is in line with the findings of Abdel Zaher et al. (2009) who showed that, fish fed diet containing different levels as $0.5,1$ and $1.5 \%$ of $T$. foenum-graecum seeds meal, increased the serum globulin significantly. The increase in the serum globulin levels is thought to be associated with a stronger innate response in fish (Wiegertjes et al., 1996). The increase in globulin was suggested previously to indicate that, fish are immunologically strong (Nayak et al., 2004).

Glutathione peroxidase and catalase activities in blood serum showed significant increase in fish groups fed on diets contained fenugreek and thyme compared to the control group. Fenugreek and thyme been reported to possess strong antioxidant properties (Yadav and Sehga 11997, Komes et al., 2011). Thyme has a strong antimicrobial and antioxidant activity due to its very high contents of thymol, p-cymene, carvacrol, eugenol and 4-allylphenol (Lee et al., 2005; Rota et al., 2008). Biphenyl compounds antioxidants in fenugreek and thyme are also strong 
antioxidants and are involved in preventing lipid peroxidation (Chatterjee et al., 2009). Fenugreek supplementation in diet resulted in lowered lipid peroxidation and increased level of antioxidants in alloxan diabetic rats (Ravikumar and Anuradha, 1999).

In this study, stimulation of the immune system of catfish as a result of feeding of thyme and fenugreek have positively impacted the resistance of fish to $A$. hydrophila infection as was indicated by the significantly lower mortality rates of fish challenged with virulent $A$. hydrophila. It was reported that fenugreek also increase disease resistance against Streptococcus agalactiae, S. iniae and Aeromonas hydrophila in Oreochromis sp. (Zilberg et al., 2010) and O. niloticus (Mostafa et al. 2009), respectively. Lee et al. (2005); Rota et al. (2008) reported that thyme has a strong antimicrobial (assessed as inhibitors of microbial growth). The antifungal and antibacterial activity exhibited by the Thymus genus essential oil has been demonstrated by several researchers (Karaman et al., 2001; Rasooli and Mirmostafa 2003)

In conculsion, Results of the current study proved that dietary supplementation of thyme and fenugreek enhanced the immune response and antioxidant effect of catfish. This modulation of the fish immunity has greatly enhanced the resistance of challenged fish to A. hydrophila. So, these herbs and spice can be used as immunostimulants to enhance the immune responses and increase the resistance of $C$. gariepinus against $A$. hydrophila and moreover they have economical benefits.

\section{REFERENCES}

Abd El-Latif, S.A.; El-Yamany, A.T. and Edaly, A.F. (2004): Evaluation of using different levels and sources of medicinal herbs in growing Japanese quail diets. Egypt. J. Nutr. And Feed, 7(1): 69-81.

Abdel Zaher, M.M.; Ahmad, H.M.; Amani, M. and Asmaa, S. (2009): Effect of Using Dried Fenugreek Seeds as Natural Feed Additives on Growth Performance, Feed Utilization, Whole-body Composition and Entropathogenic Aeromonas Hydrophilachallinge of Monsex Nile Tilapia O. Niloticus (L) Fingerlings. Australian $\mathrm{J}$ of Basic and Applied Sciences 3: 1234-1245.

Abu-Elala, N.; Marzouk, M. and Moustafa, M. (2013): Use of different Saccharomyces cerevisiae biotic forms as immune modulator and growth promoter for Oreochromis niloticus challenged with some fish pathogens. International Journal of Veterinary Science and Medicine. 1: 21-29.
Abutbul, S.; Golan-Goldhirsh, A.; Barazani, O. and Zilberg, D. (2004): Use of Rosmarinus officinalis as a treatment against Streptococcus iniae in tilapia (Oreochromis sp.). Aquaculture, 238(1-4): 97-105. Aebi, H. 1984. Methods Enzymol.105, 121-126.

Agarwal, S.S. and Singh, V.K. (1999): Immunomodulators studies on Indian medicinal plants and synthetic peptides. Part 1: medicinal plants. Proc Indian Natl Sci Acad. 65: 179-204.

Ardo, L.; Yin, G.; Xu, P.; Váradi, L. and Szigeti, G. (2008): Chinese herbs (Astragalus membranaceus and Lonicera japonica) and boron enhance the non specific immune response of Nile tilapia (Oreochromis niloticus) and resistance against Aeromonas hydrophila. Aquaculture 275: 26-33.

Austin, B. and Austin, D. (2007): Bacterial fish pathogens disease of farmed and wild fish. Dordrecht; Chichester: Springer; Published in association with PRAXIS Pub Ltd.

Bin-Hafeez, B.; Haque, R.; Parvez, S.; Pandey, S.; Sayeed, I. and Raisuddin, S. (2003): Immunomodulatory effect of fenugreek (Trigonella foenum-graecumL.) extract in mice. Int. Immunopharmacol., 3(2): 257-265.

Balfry, S.K. and Higgs, D.A. (2001): Influence of dietary lipid composition on the Immune system and disease resistance of finfish. Nutrition and Fish health book. 213-234.

Chatterjee, S.; Variyar, P.S. and Sharma, A. (2009): Stability of lipid constituents in radiation processed fenugreek seeds and turmeric: role of phenolic antioxidants. J. Agric Food Chem. 57(19): 9226-9233.

Coutteau, P.; Ceulemans, S. and Halteren, van Alexander. (2011): Botanical extracts improve productivity and economics in aquaculture, Nutriad International, Belgium.

Devasagayam, TPA. And Sainis, KB. (2002): Immune system and antioxidants, especially those derived from Indian medicinal plants. Indian J. Exp Biol. 40: 639-655.

Dorucu, M.; Ozesen, S.; Ispir, U.; Altinterim, B. and Celayir, Y. (2009): The effect of black cumin seeds, Nigella sativa, on the immune response of rainbow trout, Oncorhynchus mykiss. Mediterr. Aquacult. J. 2 (1): 27-33.

Dügenci, SK.; Arda, N. and Candan, A. (2003): Some medicinal plants as immunostimulant for fish. J. Ethnopharmacol., 88(1): 99-106.

Elkamel, A.A. and Thune, R.L. (2003): Invasion and replication of Photobacterium damselae subsp. Piscicida in fish cell lines. J. Aqua Ani Hea.15: 167-174.

Ellsaesser, C.F. and Clem, L.W. (1986): Hematological and immunological changes in channel catfish stressed by handing and transport. J. fish biol. 28: 511-521. 
Ergün, S.; Yılmaz, S. and Yigit, M. (2011): Effects of thyme, rosemary and fenugreek on some hematological and immunological parameters of tilapia, Oreochromis mossambicus. Mediterranean Aquaculture 2020, Aquaculture Europe (EAS 2011); 2011 Oct 19-21; RhodesGreece, p. 18-21.

Fernández, A.B.; Blas, I. and Ruiz, I. (2002): Immunological system in Teleost. Cells and organs. Aquatic magazine, 16, Spanish.

Frankic, T.; Voljc, M.; Salobir, J. and Rezar, V. (2009): Use of herbs and spices and their extracts in animal nutrition. Acta agriculturae Slovenica, 94(2): 95-102.

Gültepe, N.; Bilen, S.; Yılmaz, S.; Güroy, D. and Seyit Aydın1, S. (2014): Effects of herbs and spice on health status of tilapia (Oreochromis mossambicus) challenged with Streptococcus iniae. ACTA VET. BRNO 2014, 83: 000-000; doi: $10.2754 / \mathrm{avb} 201483020000$.

Hoffman, W.S. (1966): The biochemistry of clinical medicine.

Karaman, S.; Digrak, M.; Ravid, V. and Iclim, A. (2001): Antibacterial and antifungal activity of the essential oils of Thymus revolutus Celakfrom Turkey. J. Ethnopharmacol., 76: 183-186.

Kaviarasan, S.;Vijayalakshmi, K. and Anuradha, C.V. (2004): Polyphenol-rich extract of fenugreek seeds protect erythrocytes from oxidative damage. Plant. Foods. Hum. Nutr. 59(4): 143147.

Kwahara, E.; Ueda, T. and Nomura, S. (1991): In vitrophagocytic activity of white spotted shark cells after injection with Aeromonas salmonicida extracelluar products. Fish Pathology 26: 213-214.

Khalil, R.H. (2000): Streptococcosis as a cause of massive mortality among Nile tilapia (Oreochromis niloticus). 9 th SCI. Cong. Fac. Vet. Med., Assi. Univ., Egy. 366-377.

Komes, D.; Belščak-Cvitanović, A.; Horžić, D.; Rusak, G.; Likić, S. and Berendika, M. (2011): Phenolic composition and antioxidant properties of some traditionally used medicinal plants affected by the extraction time and hydrolysis. Phytochem Anal 22(2):172-180.

Lee, K.W.; Everts, H.; Kappert, H.J.; Frehner, M.; Losa, R. and Beynen, A.C. (2003b): Dietary Carvacrol lowers body weight gain but improves feed conversion in female broiler chickens. J. Appl. Poult. Res., 12: 394-399.

Lee, K.J.; Dabrowski, K.; Sandoval, M. and Miller, M.J.S. (2005): Activity-guided fractionation of phytochemicals of maca meal, their antioxidant activities and effects on growth, feed utilization and survival in rainbow trout (Oncorhynchus mykiss) juveniles. Aquaculture, 244(1-4): 293-301.
Misra, C.K.; Das, B.K.; Mukherjee, S.C. and Pattnaik, P. (2006): Effects of long term administration of dietary b-glucan on immunity, growth, and survival of Labio rohita fingerlings. Aquaculture.255:82-94.

Mostafa, A.A.Z.M.; Ahmad, M.H.; Mousallamy, A. and Samir, A. (2009): Effect of using dried fenugreek seeds as natural feed additives on growth performance, feed utilization, wholebody composition and entropathogenic Aeromonas hydrophila-challenge of monsex Nile Tilapia O. niloticus (L) fingerlings. Aust. J. Basic Appl. Sci., 3(2): 1234-1245.

Nakanishi, T.; Aoyagi, K.; Xia, C.; Dijkstra, J.M. and Ototake, M. (1999): Specific cell-mediated immunity in fish. Vet. Immunol Immunopathol.72: 101-109.

Nayak, A.K.; Das, B.K.; Kohli, M.P. and Mukherjee, S.C. (2004): The immunosuppressive effect of alpha-permethrin on Indian major carp, rohu (Labeo rohita Ham.). Fish Shellfish Immunol 16: 41-50

Paglia, D.E. and Valentine, W.N. (1967): J. Lab. Clin. Med. 70: 158-169.

Paul, B.N.; Sarkar, S.; Mukhopadhyay, P.K. and Mohanty, S.N. (2004): Effect of dietary attractant on feed utilisation and growth of Rohu Labeorohita (Ham.) fry. Anim. Nutr. Feed. Techn. 4(2): 145-152.

Pérez-Rosés, R.; Ester Risco, E.; Vila, R.; Peñalver, $P$. and Cañigueral, S. (2015): Effect of Some Essential Oils on Phagocytosis and Complement System. Activity J. Agric. Food Chem., 63 (5), pp 1496-1504

Rasooli, I. and Mirmostafa, S.A. (2003): Bacterial susceptibility to and chemical composition of essential oils from Thymus kotschyanus and Thymus persicus. J. Agric. Food Chem., 51: 2200-2205.

Ravikumar, P. and Anuradha, C.V. (1999): Effect of fenugreek seeds on blood lipid peroxidation and antioxidants in diabetic rats. Phytother Res 13(3): 197-201.

Rota, M.C.; Herrera, A.; Martinez, R.M.; Sotomayor, J.A. and Jordan, M.J. (2008): Antimicrobial activity and chemical composition of Thymus vulgaris, Thymus zygis and Thymus hyemalis essential oils. Food Control. 19(7): 681-687.

Sakai, M. (1999): Current research status of fish immunostimulants. Aquaculture.172: 63-92.

Saleh, N.; Ali, T.; Abd El-latif, A. and 1Emad Ghazy, E. (2014): The Effects of Dietary Supplementation of Different Levels of Thyme (Thymus vulgaris) and Ginger (Zingiber officinale) Essential Oils on Performance, Hematological, Biochemical and Immunological Parameters of Broiler Chickens. Global Veterinaria 12 (6): 736-744 
S.A.S. (2001): SAS/STAT Guide for personal computer (version 8.2 End). SAS. INST., Cary, N.C.Co., New York.

Secombes, C.J. (1994): Enhancement of fish phagocyte activity. Fish Shellfish Immunol. 4: 421-436.

Shalaby, A.M.; Khattab, Y.A. and Abdel Rahman, A.M. (2006): Effects of garlic (Allium sativum) and chloramphenicol on growth performance, physiological parameters and survival of Nile tilapia (Oreochromis niloticus). J. Venom. Anim. Toxins., 12(2): 172-201.

Steel, R.G. And Torrie, J.H. (1982): Principles and procedures of statiostics. A biometrical approach $\left(2^{\text {nd }} \mathrm{Ed}\right)$ Mc Grow-Hill Book.

Toghyani, M.; Toghyani, M.; Mohammad rezaei, M.; Gheisari, A.; Tabeidian, S.A. and Ghalamkari, G. (2011): Effect of Cocoa and Thyme Powder Alone or in Combination on Humoral Immunity and Serum Biochemical Metabolites of Broiler Chicks. In the Proceedings of the 2011 Intern. Agric. Anim. Sci. Conf., IACSIT Press, Singapore.

Tollba, A.A.H.; Shabaan, S.A.M. and Abdel-Mageed, M.A.A. (2010): Effects of using aromatic herbal extract and blended with organic acids on productive and physiological performance of poultry 2- the growth during cold winter stress. Animal Prod Inst Giza 1: 229-248.

Wiegertjes, G.F.; Stet, R.J.; Parmentier, H.K. and van Muiswinkel, W.B. (1996): Immunogenetics of disease resistance in fish: a comparative approach. Dev Comp Immunol 20: 365-381.

Yadav, S.K. and Sehgal, S. (1997): Effect of home processing and storage on ascorbic acid and beta-carotene content of Bathua (Chenopodium album) and fenugreek
(Trigonella foenum graecum) leaves. Plant Foods Hum Nutr 50(3): 239-247.

Yllmaz, S. and Ergün, S. (2011): Effect of red pepper (Capsicum annum) on pigmentation of blue streak hap (Labidochromis caeruleus). The Israeli Journal of Aquaculture - Bamidgeh. 63: IIC:63. 2011.633.

Yllmaz, S. and Ergün, S. (2012a): Effects of medicinal herb extracts on egg hatching of the angel fish (Pterophyllum scalare). Kafkas. Univ. Vet. Fak. Derg., 18(2): 185-189.

Yılmaz, S. and Ergün, S. (2012b): Effects of garlic and ginger oils on hematological and biochemical parameters of sea bass, Dicentrarchus labrax. J. Aquat. Anim. Health. 24(4): 219-224.

Yllmaz, S.; Ergün, S. and Türk, N. (2012): Effects of cumin-supplemented diets on growth and disease (Streptococcus iniae) resistance of tilapia (Oreochromis mossambicus). The Israeli Journal of Aquaculture - Bamidgeh, 64:IJA_768.

Yllmaz, S.; Ergün, S. and Soytaş, N. (2013): Herbal supplements: useful tools for preventing streptococcal disease during first-feeding of tilapia fry, Oreochromis mossambicus. The Israeli Journal of Aquaculture - Bamidgeh (in press).

Yunxia, Q.; Jianzhong, S. and Guoliang, W. (2001): A review of principal bacterial diseases of mariculture fish. Transactions of Oceanology and Limnology. 2: 78-87.

Zilberg, D.; Tal, A.; Froyman, N.; Abutbul, S.; Dudai, N. and Goldhirsh, A.G. (2010): Dried leaves of Rosmarinus officinalis as a treatment for streptoccosis in tilapia. J. Fish diseases. 33: 361-369.

\section{المحفزات المناعية للزعتر والحلبة فى الاسماك القطية (القراميط)

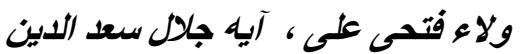

ان الهدف من هذه الدراسة هو التحقق من حدوث تنشيط فى الجهاز المناعى لاسماك القراميط عند تغذيتها على الزعت عتر و الحلبة

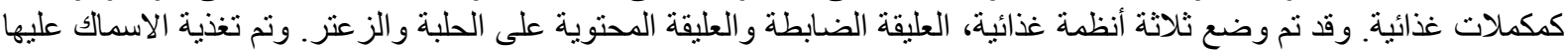

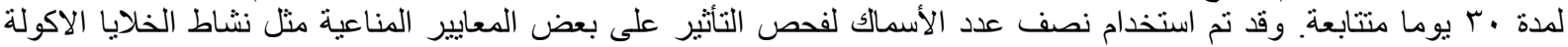

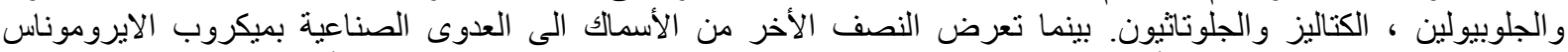

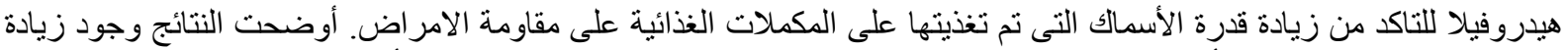

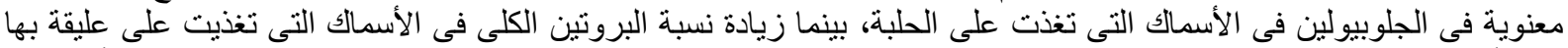

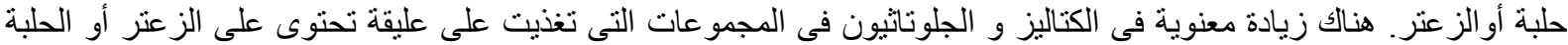

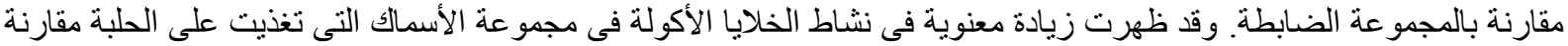

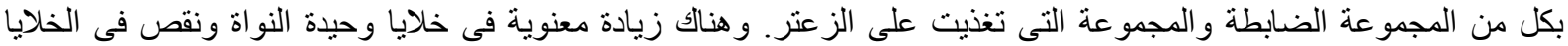

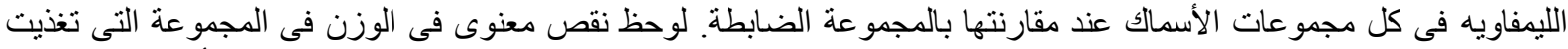

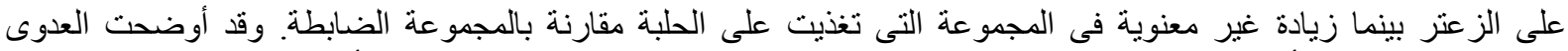

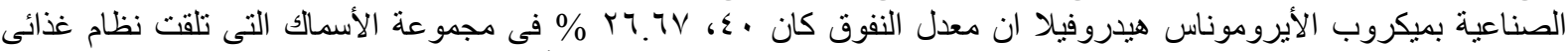

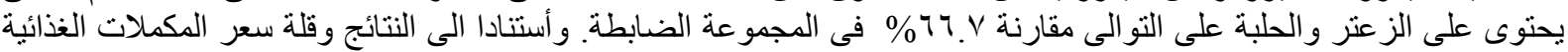
يوصى الباحثون باستخدام الزعتر والحلبة كمكمل غذائي فى عليقة الأسماك للحد من نسبة النفوق الناجمة من بعض مسببات الأمر اض. 